\title{
EVALUATING THE EFFECT OF STATE AID TO BUSINESS BY MULTICRITERIA METHODS
}

\author{
Romualdas Ginevičius ${ }^{1}$, Valentinas Podvezko², Šarūnas Bruzgẻ ${ }^{3}$ \\ Vilnius Gediminas Technical University, \\ Saulètekio al. 11, LT-10223Vilnius, Lithuania.E-mail: ${ }^{3}$ sarunas@finovus.lt
}

Received 8 October 2007; accepted 12 August 2008

\begin{abstract}
One of the forms of state intervention in market development is state aid (subsidies) to private sector enterprises. Over the period of 2004-2006, a great part of the EU aid was granted to business in Lithuania through the EU structural funds. State aid is a complicated phenomenon. It may have several aims, with none of them being dominant. The effects of this aid may also be varied and hardly described by a single criterion or indicator. Therefore, multiple criteria evaluation methods can be used to compare the aid to various businesses and to determine its effect on their development objectively.

The analysis of state subsidies to enterprises based on these methods allowed us to state that the aid had the greatest effect on the development of projects in the areas of production, research, experiments and education. The most influencing factor is aid intensity (the more intensive the aid, the greater the effect), while the best ratios of investments to the effect obtained was found in the area of educational projects, followed by research, experimental and production projects. The aid to enterprises providing services was the least effective.

The results obtained in multicriteria evaluation of state aid to business show that these methods are well suited to the analysis of this phenomenon, providing an objective view of the picture.
\end{abstract}

Keywords: state aid, aid assessment, EU support, structural funds, multicriteria methods, expert estimates.

\section{Introduction}

Under current economic conditions, market development is regulated by the market itself. However, the role of the state in economy is still considerable, and the market can hardly successfully operate without state interference. State intervention in market operation can have both pluses and minuses, e.g. it can lead to distortion of competition, slowdown of business development, unemployment, etc. Therefore, intervention methods should be carefully considered and assessed. One of the forms of state intervention in market development is state aid (subsidies) to private sector enterprises. Over the period of 2004-2006, a great part of the EU aid was granted to business in Lithuania through the EU structural funds. Taking into account the fact that the EU support for Lithuania over the period of 2007-2013 will be considerably larger than that provided in 2004-2006, the appropriate allocation of financial resources, most of which are still going to be invested in business, should be ensured. For this purpose, the effect of state subsidies on enterprise performance should be determined first.
The problem of state aid to business was analysed by many scientists, both in the EU and all over the world (Bond, Samuelson 1986; Doyle, Wijnbergen 1984; Black, Hoyt 1989). A number of studies were ordered by various EU institutions (Hagens, Bekker, Gaaff 1994; Venetoklis 1998; Bachtler, Michie 1995), but all of them emphasized only some particular aspects associated with the provision or estimation of aid. However, many problems relating to the type of aid, its extent, form, intensity and addressees, as well as the factors influencing its „success“ or „failure“, have not been solved yet.

Subsidizing enterprises is a complex process which may have many aims, with none of them being dominant. The results (effects) of subsidizing may also be varied and can hardly be described by a single criterion which could embrace all aspects of the considered phenomenon, reflecting a general result. The criteria of such evaluation found in the programming document of Lithuania for 2004-2006 are given in broad terms and can hardly fully describe the effect of the EU support on business. (Lithuanian General Programming Document for the years 2004-2006, 2004). For 
comprehensive evaluation of the problem, the number of the criteria should be considerably increased. However, the process is complicated because the types and significances of particular criteria should be taken into account (it should be noted that the criteria are not equally important) (Ginevičius, Podvezko 2005, 2007a, 2007 b; Tamošiūnienè, Šidlauskas, Trumpaite 2006). For this purpose, quantitative multicriteria evaluation methods (Hwang, Yoon 1981; Figueira, Greco, Ehrgott 2005) were used in the present investigation.

The paper presents the investigation of the EU aid to enterprises, based on the use of multicriteria evaluation methods. The effect of providing state subsidies through the EU structural funds is studied. The investigation methods include a survey, multicriteria evaluation techniques and correlation analysis. The main problems addressed are as follows: what are the key factors determining the effect of assistance? what kind of aid is required? what should be its size or scale to achieve the best result? in what area of activities can the greatest effect be achieved?

\section{A review of state aid in the European Union}

State aid is a kind of state intervention for promoting economic development. However, the support of a particular economic activity can distort market competition because state supported enterprises become more competitive than those not getting such aid. As a result, state subsidizing of enterprises may present a threat to effective operation of the local market. Being aware of the risks, the developers of the European Community's (EC) consolidated Treaty created a system of state aid regulation by restricting its provision to some particular cases (Nicolaides, Kekelekis, Buyskes 2005).

The main laws regulating state aid can be found in Articles 87-89 of the EC Treaty. Paragraph 1 of Article 87 presents the law stating that state aid is incompatible with common market, while, in paragraph 2 , the cases when it can be considered compatible with common market are listed (a decision is made by the European Commission (EC)) (State Aid Guide 2007).

EU state financing of enterprises is considered to be state aid, when

- it is based on the use of state financial resources (state or municipality budgets or funds, etc.) or is state supported;

- provides enterprises with exceptional economic benefits which they could not get under market conditions;

- it is intended for manufacturing some particular products or providing some particular services or is granted to some particular enterprises;
- it distorts or can distort competition and affects trade between the EU member-states.

- State aid is considered to be aid meeting the abovementioned conditions (criteria) (State Aid Guide 2007).

Since the EU state aid is granted only in some exceptional cases, the latter are the subject of discussion. It is of paramount importance that, in these cases, aims and conditions of aid provision be clearly defined.

In the states of transition economies, like Lithuania, promotion of economic development is one of the main objectives. The aims of direct business aid may embrace encouraging of the development and increase of efficiency of production or other sectors and activities (e.g. research and development, implementation of innovations, etc.), as well as solution of problems caused by imperfect market conditions (Nicolaides, Kekelekis, Buyskes 2005).

These problems can arise in the regions experiencing an economic crisis or at enterprises having some difficulties, etc. It should be noted that the competitive markets can effectively solve these problems themselves. State intervention can be justified only when self-regulation is impossible or takes a long time without the external aid. State support is also justified, when the growth of a particular sector or the economy as a whole, cannot, for some reason, be accelerated without the interference from the outside (Nicolaides, Kekelekis, Buyskes 2005).

The General Programming Document (GPD), defines the main areas of granting the EU aid to Lithuanian business in 2004-2006 as follows: to provide the conditions for long-term increase of national economy competitiveness, to accelerate the transfer to knowledge economy characterized by continually growing gross national product (GNP) and high employment index, and to increase the rate of knowledge economy development ensuring higher living standard and welfare of all Lithuanian people (Lithuanian General Programming Document for the years 2004-2006, 2004).

In spite of the aims declared, state aid may adversely affect competition, as well as distorting the market, etc. To avoid this, the EU is urging that state intervention encourage structural changes, not affecting the operation of local market and distorting the competition between enterprises of the EU member-states (Nicolaides, Kekelekis, Buyskes 2005).

The rules of state aid provision contribute to effective operation of common market in two ways: 
- preventing from state interference which could greatly distort competition and helping to maintain fair market conditions for business in all EU member-states;

- allowing to grant aid for promoting economic development and achieving other goals of public policy, when aid benefits make up for any competition distortion.

In the absence of state aid rules, providing preferential terms to some particular enterprises would harm other market sector players as well as presenting a threat of distorting competition. It would also prevent from maintaining long-term competitiveness of the EC enterprises.

To avoid an adverse effect of state intervention in market economy (in the form of state aid), rigorous control is required along with clearly defined rules of state aid provision.

Though the EC assumed the responsibility to reduce state aid, it is still considerable. The amount of state aid in $25 \mathrm{EU}$ member-states was 82.9 billion EUR in 1992, reaching 66.7 billion EUR in 2006 (State Aid Control 2007).

\section{The problem of business state aid effect and its economic assessment}

The problem of the effect of state aid to business has been in the focus of the economists' attention for a long time (Bond, Samuelson 1986; Doyle, Wijnbergen 1984; Black, Hoyt 1989). State intervention may have a strong impact on market operation because the incentives created by this aid for some enterprises may greatly worsen the conditions for their competitors operating in the same or other countries. The benefit of subsidies often results in the delay of inevitable restructuring. Non-subsidized enterprises competing with state-supported companies on the market can lose their competitive edge. In addition, they face a higher risk of unemployment. As a result, not only the local market may suffer from this aid, but the competitiveness of European economy may be threatened as well (Nicolaides, Kekelekis, Buyskes 2005).

State aid may be of different categories (e.g. subsidies, tax reduction, etc.) therefore, its effect was assessed from various perspectives. Thus, E. Bond and L. Samuelson (1986), as well as C. Doyle and S. van Wijnbergen (1984), considered the role of tax reduction in attracting companies to a particular area. D. Black and W. Hoyt (1989) analysed the effect of providing extra public services to business enterprises. M. Keen and
M. Marchand (1997) investigated the impact of the structure of public expenses on capital distribution in the state.

T. Besley and P. Seabright (1998) believe that the state aid policy should be based on the same principles as any other state policy related to public expenses. This refers to the effectiveness of public expenses, implying that the profit created by financial resources should exceed the alternative profit obtained if the resources were used for financing other things.

State aid is a complicated phenomenon. It may have several aims, with none of them being dominant. The effects of this aid may also be varied and hardly described by an integrated criterion or indicator, which could describe all aspects of this process and its general (complex) effect. Seeking to evaluate the effect of financial aid to business the number of criteria describing the aid should be increased. In addition, the significance of the selected criteria should be taken into account (it should be noted that criteria are not equally important) (Ginevičius, Podvezko 2005, 2007a, 2007b; Tamošiūnienè, Šidlauskas, Trumpaite 2006). This aim can be achieved by using quantitative multicriteria evaluation methods.

The possibility to use a set of criteria describing the considered object which are assigned different significances was a key factor determining the choice of multicriteria evaluation methods for the present investigation.

\subsection{Complex evaluation of direct business aid through structural funds of the European Union}

When Lithuania became a member-state of the European Union on May 1, 2004, the EU financial aid to Lithuania was considerably increased. The aid granted to Lithuania before it joined the European Union, which was intended for it to get prepared for the EU membership, was replaced by much more considerable aid granted through the EU structural and cohesion funds. In the period of 2004-2006, the aid through the EU structural funds was granted to Lithuania according to the General Programming Document. It defines the aims of the EU structural funds and Lithuanian actions, as well as the development strategy and payments through the EU structural funds and other sources of financing. The appropriate allocation of the obtained financial resources should be ensured, taking into account the size and category of aid granted through the EU structural funds. For this purpose, the effect of the aid should be properly evaluated. 
Most of aid assessment methodologies were developed as early as in the 60 -s of the last century and later. The works of M. Scriven (1967, 1991), M. Patton (1986, 1996), W. Shadish, T. Gook and L. Leviton (1991), H. Chen (1990), E. Guba and Y. Lincoln (1981, 1989), P. Rossi and H. Freeman (1989) are just few examples. Unfortunately, all the theories have some drawbacks and none of them has been widely accepted. After the reform of the EC structural funds, the assessment of the effect of the aid programmes became compulsory. According to regulations, ex-ante, on-going and ex-post assessments should be made to demonstrate the effect of the programme (Hagens, Bekker, Gaaff 1994). Since that time every EU member-state regularly performs the above assessments (Venetoklis 1998). Since 1993, more than 300 individual structural funds' assessments have been made (Bachtler, Michie 1995).

Based on laws and other legal EU and Lithuanian documents regulating the EU financial aid to enterprises, four main areas of aid provision may be defined: development of production, research, experimenting and services. The present investigation will be focussed on the analysis of aid granted to enterprises operating in these areas. Finally, the results obtained in investigating the effect of the financial aid will be compared to determine in what area of enterprise activities this effect is the greatest. This aim can be achieved because the same criteria and research methods are used throughout the analysis. The addition of the criteria describing the aid itself to the evaluation results will allow us to identify factors having the greatest influence on the considered phenomenon.

\subsection{Generating the criteria of evaluation}

Trying to answer the question what financial resources should be granted to enterprises and how it should be done to achieve the highest effect, the criteria describing the aid itself were determined first. This procedure was based on the provisions of laws and other legal documents regulating the EU financial aid to Lithuania. Since such criteria as, for example, absolute amount of subsidy provided to an enterprise, which does not take into account the enterprise size, can mislead us about the real extent of the aid granted to it, and because other factors, such as enterprise previous experience in executing similar projects, its preparedness to implement the project, etc. are important for the final result, some additional criteria were included in the analysis. Finally, seven criteria were determined:

1. Financial aid (through the EU or state funds, in litas) intensity (aid expressed as a percentage of project value).
2. Size of financial aid (EU or state financial resources, in litas).

3. Size of financial aid (EU or state financial resources, percentage of enterprise annual turnover).

4. The share of project financing by the own capital of an enterprise (a percentage of project value).

5. The share of project financing by the borrowed capital (if used) (a percentage of project value).

6. The preparedness of an enterprise to implement the project (the availability of human resources, the required documents, e.g. a detail design, etc.) (assessed in points 1-10).

7. Previous enterprise experience in implementing similar projects (assessed in points 1-10).

In addition to the criteria describing the aid to an enterprise, the criteria defining its effect are also determined. Based on the aims of the EU financial aid to enterprises and laws regulating this aid, the following fifteen criteria were selected:

1. The number of newly created workplaces (in units).

2. The number of saved workplaces (workplaces which could be eliminated without the financial aid) (in units).

3. The contribution of the implemented project to the achievement of enterprise aims (assessed in points $1-10)$.

4. The impact of financial aid on enterprise competitiveness (assessed in points 1-10).

5. The impact of financial aid on enterprise market share (assessed in points 1-10).

6. The impact of financial aid on the competitiveness of the branch of industry (assessed in points $1-10)$.

7. The impact of financial aid on enterprise efficiency (assessed in points 1-10).

8. The impact of financial aid on the surplus value created by enterprise workers (surplus value created by the worker per hour) (assessed in points $1-10)$.

9. The impact of the financial aid on surplus value created by an enterprise (assessed in points 1-10).

10. The impact of the financial aid on the expenses on research and development (a percentage of enterprise turnover) (assessed in points 1-10).

11. The impact of the financial aid on the export of enterprise products (assessed in points 1-10).

12. The impact of the financial aid on the environmental effect of production (assessed $1-10)$.

13. The impact of the financial aid on social and economic development of the region (assessed in points 1-10). 
14. The impact of the financial aid on the development of equal rights (assessed in points 1-10).

15. The impact of the financial aid on the development of information society (assessed in points 1-10).

Most of the criteria described above cannot be expressed in any particular units, therefore, in this study, their significance is assessed against the 10-point scale, with 1 meaning the neutral impact, while 10 implies the highest positive effect.

Based on the criteria generated, two representative samples obtained in surveys were analysed. A survey of enterprises granted the state aid was aimed at obtaining the values of the criteria of aid and aid effect on enterprise performance. The data of the survey are presented in Table 1. The second survey was made of the EU aid experts. It was aimed at determining the significance of the criteria selected.

\subsection{Multicriteria evaluation of enterprises}

In recent years, quantitative multicriteria evaluation methods have been widely analysed and used in various areas, the number of which was continually growing (Hwang, Yoon 1981; Figueira, Greco, Ehrgott 2005; Ginevičius 2008; Ginevičius, Podvezko 2001, 2005, 2007a, 2007b; Ginevičius, Podvezko, Mikelis 2004; Podvezko 2005, 2007). Since the EU financial aid is multiobjective, it may be referred to investment problems, when the decision maker seeks to achieve more than one aim.

Quantitative methods are based on matrix $R=\left\|r_{i j}\right\|$ of the statistical data (or expert estimates) of the criteria describing the objects compared and the values of the criteria significances (weights) $\omega_{1}, i=1, \ldots, m ; j=1, \ldots, n$, where $m$ is the number of criteria, $n$ is the number of the compared objects (enterprises). Using quantitative multicriteria evaluation methods it is necessary to determine if a criterion is maximizing or minimizing. The largest values are the best for maximizing criteria, while the smallest values are the best for minimizing criteria. The criteria of quantitative multicriteria methods usually integrate non-dimensional normalized criteria values $\tilde{r}_{i j}$ and criteria weights $\omega_{1}$ into a single quantity, i.e. the criterion of the method. Most of the methods use different normalization or transformation techniques of the initial data (the criteria values).

Multicriteria methods are of various complexity. The most widely used method is Simple Additive Weighing (SAW) (Hwang, Yoon 1981; Ginevičius, Podvezko 2004a, 2006, 2007a; Ginevičius, Butkevičius, Podvezko 2005,2006$)$.
The criterion of the method $S_{j}$ reflects the main idea of quantitative multicriteria methods consisting in integration of the criteria values and weights into a single quantity.

The sum $S_{j}$ of the weighted normalized values is calculated for each $j$-jh object. It can be obtained from the formula (Hwang, Yoon 1981; Ginevičius, Podvezko 2004a, 2004b, 2006, 2007a):

$$
S_{j}=\sum_{i=1}^{m} \omega_{i} \tilde{r}_{i j},
$$

where $\omega_{i}$ is weight of $i$-th criterion; $\tilde{r}_{i j}$ is normalized $i$-th criterion value for $j$-th object $\left(\sum_{i=1}^{m} \omega_{i}=1\right)$.

In this case, normalization of the initial data can be made by the formula (Ginevičius, Podvezko 2001, 2006):

$$
\tilde{r}_{i j}=\frac{r_{i j}}{\sum_{i=1}^{m} r_{i j}},
$$

where $r_{i j}$ is $i$-th criterion value for $j$-th object.

The best value of the criterion $S_{j}$ is the largest value. The simplest of all the methods used in the present investigation is the sum of the ranks of all the criteria (VS). The criterion of the method $V_{j}$ for each $j$-th object is determined by the formula (Ginevičius, Podvezko 2001, 2006):

$$
V_{j}=\sum_{i=1}^{m} m_{i j},
$$

where $m_{i j}$ is $i$-th criterion rank for $j$-th object $\left(1 \leq m_{i j} \leq\right.$ $m)$. The best value of the criterion $V_{j}$ is the smallest value. The values of the criterion $V_{j}$ are not dependent either on normalization technique of the initial data or transformation of their scale or the values $(i=1, \ldots, m)$ of the criteria weights $\omega_{i}$. An indispensable condition of using this method is prior determination of the criteria type (which may be maximizing or minimizing). Minimizing criteria can be converted into maximizing criteria by the formula (Hwang, Yoon 1981; Zavadskas, Kaklauskas 2007; Ginevičius, Podvezko 2004a, 2006, 2007a; Zavadskas, Turskis 2008):

$$
\tilde{r}_{i j}=\frac{\min _{j} r_{i j}}{r_{i j}},
$$

where $r_{i j}$ is $i$-th criterion value for $j$-th object. Then, the smallest criterion value will be the largest value equal to unity (one). 


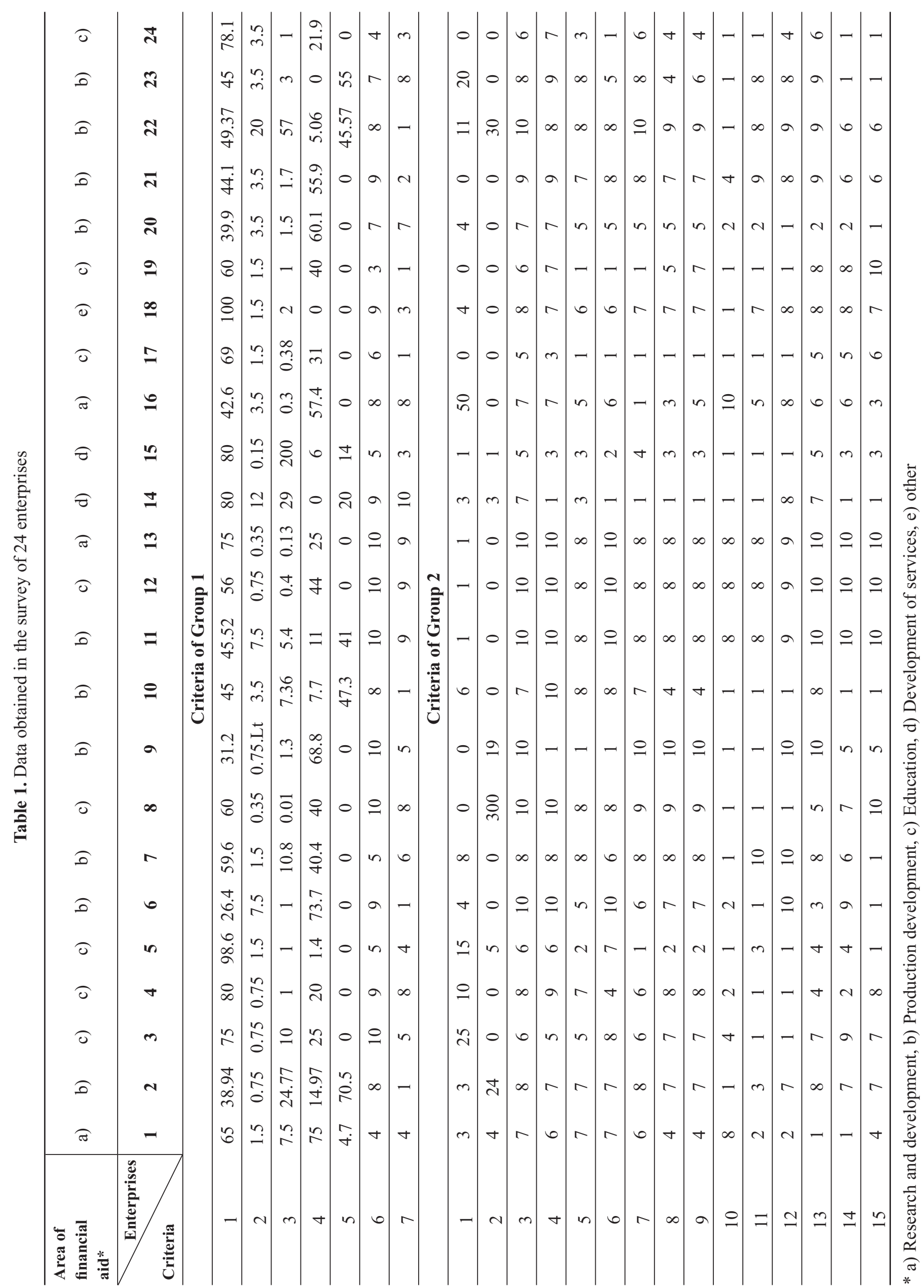


The calculations show that the use of the above criterion may be justified at the initial stage of evaluation, though the results obtained by using the VS method, i.e. ranking of the objects, do not differ much from those yielded by sophisticated mathematical approaches.

Another relatively simple method is geometric mean of normalized values of all criteria $(\mathrm{GV})$. The criterion of the method $\Pi_{j}$ can be obtained by the formula (Ginevičius, Podvezko 2001, 2006; Kalibatas, Turskis 2008):

$$
\Pi_{j}=\sqrt[m]{\prod_{i=1}^{m} \tilde{r}_{i j}} .
$$

The priority order of the objects established by formula (5) does not depend on the criteria weights $\omega_{i}$, therefore, this quantity is not included in the formula. The best value of the criterion $\Pi_{j}$ is the largest value.

Method GV is not applicable if at least one $r_{i j}$ value is negative or equal to zero. Minimizing criteria should be converted to maximizing ones by formula (4).

Complex evaluation of the effect of state aid (subsidies) to enterprises was not only based on application of simple methods. More sophisticated approaches, e.g. TOPSIS (Hwang, Yoon 1981; Zavadskas, Kaklauskas 2007; Ginevičius, Podvezko 2004a, 2006, 2007a, 2007b; Ustinovičius, Zavadskas 2004; Opricovic, Tzeng 2004) and VIKOR (Opricovic, Tzeng 2004; Zavadskas, Antuchevičienè 2006) were also used.

These methods can be applied both to maximizing and minimizing criteria.

TOPSIS is based on vector normalization:

$$
\tilde{r}_{i j}=\frac{r_{i j}}{\sqrt{\sum_{j=1}^{n} r_{i j}^{2}}}(i=1, \ldots, m ; j=1, \ldots, n),
$$

where $\tilde{r}_{i j}$ is normalized value of $i$-th criterion for $j$-th object.

The best solution (alternative) $V^{*}$ and the worst one $V^{-}$are calculated by the formulas:

$$
\begin{aligned}
& V^{*}=\left\{V_{1}^{*}, V_{2}^{*}, \ldots, V_{m}^{*}\right\}=\left\{\left(\max _{j} \omega_{i} r_{i j} / i \in I_{1}\right),\right. \\
& \left.\left(\min _{j} \omega_{i} \tilde{r}_{i j} / i \in I_{2}\right)\right\}, \\
& V^{-}=\left\{V_{1}^{-}, V_{2}^{-}, \ldots, V_{m}^{-}\right\}=\left\{\left(\min _{j} \omega_{i} r_{i j} / i \in I_{1}\right),\right. \\
& \left.\left(\max _{j} \omega_{i} \tilde{r}_{i j} / i \in I_{2}\right)\right\},
\end{aligned}
$$

where: $I_{1}$ is a set of maximizing criteria; $I_{2}$ is a set of minimizing criteria, $\omega_{i}$ is weight of $i$-th criterion $\left(\sum_{i=1}^{m} \omega_{i}=1\right)$.
The distance of each alternative to the best solutions $D_{j}^{*}$ and to the worst solutions $D_{j}^{-}$is calculated by the formulas:

$$
\begin{aligned}
& D_{j}^{*}=\sqrt{\sum_{i=1}^{m}\left(\omega_{i} \tilde{r}_{i j}-V_{i}^{*}\right)^{2}}, \\
& D_{j}^{-}=\sqrt{\sum_{i=1}^{m}\left(\omega_{i} \tilde{r}_{i j}-V_{i}^{-}\right)^{2}} .
\end{aligned}
$$

The criterion $C_{j}^{*}$ of the method TOPSIS is calculated by the formula:

$$
\begin{aligned}
& C_{j}^{*}=\frac{D^{-}}{D_{j}^{*}+D_{j}^{-}}(j=1, \ldots, n) \\
& \left(0 \leq C_{j}^{*} \leq 1\right) .
\end{aligned}
$$

The largest value of the criterion $C_{j}^{*}$ corresponds to the best alternative. The alternatives compared should be ranked (arranged) in the descending order.

A compromising classification method VIKOR, like TOPSIS, assesses the distance to the best ('ideal') solution, providing compromise alternatives in the case when evaluation criteria are controversial.

VIKOR is based on the following normalization for maximizing criteria:

$$
\begin{aligned}
& \tilde{r}_{i j}=\frac{\max _{j} r_{i j}-r_{i j}}{\max _{j} r_{i j}-\min _{j} r_{i j}} \\
& \left(0 \leq \tilde{r}_{i j} \leq 1\right) .
\end{aligned}
$$

The method uses three evaluation criteria $S_{j}, R_{j}, Q_{j}(j=$ $1, \ldots, n)$.

The criteria $S_{j}$ and $R_{j}$ are calculated by the formulas:

$$
\begin{gathered}
S_{j}=\sum_{i=1}^{m} \omega_{i} \tilde{r}_{i j}, \\
R_{j}=\max _{i}\left(\omega_{i} \tilde{r}_{i j}\right) .
\end{gathered}
$$

The main generalizing criterion $Q_{j}$ is calculated by the formula:

$$
Q_{j}=\frac{v\left(S_{j}-S^{*}\right)}{\left(S^{-}-S^{*}\right)}+\frac{(1-v)\left(R_{j}-R^{*}\right)}{\left(R^{-}-R^{*}\right)},
$$

where

$S^{*}=\min _{j} S_{j}, S^{-}=\max _{j} S_{j}, R^{*}=\min _{j} R_{j}, R^{-}=\max _{j} R_{j} ;$ $v$ is the majority criterion, a strategic weight (in this case, $v=0.5$ ).

The smallest values of the criteria $S_{j}, R_{j}$, and $Q_{j}$ refer to the best evaluated alternatives, therefore, the alternatives compared should be ranked in the ascending order. 
The criteria weights are usually determined by experts. There is a number of weight determination methods, ranging from criteria ranking and direct evaluation to pairwise comparison of criteria, AHP, a method suggested by T. Saaty (Analytic Hierarchy Process) (Saaty 1980; Ginevičius, Podvezko, Andruškevičius 2004; Ginevičius, Podvezko 2004c, 2005; Hwang, Yoon 1981; Ustinovičius, Zavadskas 2004). The present analysis is based on the method of direct evaluation (Ginevičius, Podvezko 2004c), when each expert determines each criterion weight as a percentage so that the sum of weights of all the criteria would make $100 \%$.

The estimates of seven criteria of Group 1 elicited from eight experts are given in Table 2. Based on them, the average estimate of each criterion values as well as the criteria weights $\omega_{i}$ (as a 100-th of the average value) were calculated. The sum of the criteria weights $\omega_{i}$ is equal to unity (one) (see Table 2, last column).

The estimates of fifteen criteria of Group 2 elicited from eight experts are presented in Table 3. Based on these data, average values of each criterion estimates as well as criteria weights $\omega_{i}$ were calculated (see Table 3 , last column).

Weight values can be used in further multicriteria evaluation if expert estimates are in agreement (consistent). The degree of agreement can be determined by M. Kendall's concordance coefficient $W$ (Kendall 1970; Podvezko 2005, 2007; Turskis et al. 2006; Zavadskas, Vilutiene 2006; Viteikienè, Zavadskas 2007). Prior to calculating the concordance coefficient the criteria should be ranked with respect to every expert, implying that the most significant criterion is assigned the highest value equal to unity, while the second most important criterion (for object evaluation) is given the value of two, etc. The value assigned to the least significant criterion is $m$, where $m$ is the number of evaluation criteria. Similar estimates are given the same rank which is the arithmetic mean of the closest ranks (Kendall 1970; Podvezko 2005, 2007; Bardauskienè 2007).

The evaluation of Group 1 criteria by their ranking is shown in Table 4.

Table 2. Expert estimates of Group 1 criteria weights

\begin{tabular}{|c|c|c|c|c|c|c|c|c|c|c|}
\hline \multirow{2}{*}{ Criterion } & \multicolumn{8}{|c|}{ Experts } & \multirow{2}{*}{ Total } & \multirow{2}{*}{ Weight } \\
\hline & 1 & 2 & 3 & 4 & 5 & 6 & 7 & 8 & & \\
\hline 1 & 30 & 20 & 20 & 28 & 28 & 25 & 25 & 20 & 196 & 0.245 \\
\hline 2 & 13 & 11 & 20 & 10 & 24 & 5 & 25 & 7.5 & 115.5 & 0.144 \\
\hline 3 & 12 & 13 & 10 & 22 & 15 & 5 & 3 & 7.5 & 87.5 & 0.109 \\
\hline 4 & 25 & 15 & 12 & 5 & 12 & 22 & 18 & 15 & 124 & 0.155 \\
\hline 5 & 10 & 15 & 10 & 7 & 3 & 3 & 5 & 10 & 63 & 0.079 \\
\hline 6 & 5 & 20 & 16 & 15 & 8 & 25 & 12 & 20 & 121 & 0.151 \\
\hline 7 & 5 & 6 & 12 & 13 & 10 & 15 & 12 & 20 & 93 & 0.116 \\
\hline Total & 100 & 100 & 100 & 100 & 100 & 100 & 100 & 100 & 800 & 1.0 \\
\hline
\end{tabular}

Table 3. Expert estimates of Group 2 criteria weights

\begin{tabular}{|c|c|c|c|c|c|c|c|c|c|c|}
\hline \multirow{2}{*}{ Criterion } & \multicolumn{8}{|c|}{ Experts } & \multirow{2}{*}{ Total } & \multirow{2}{*}{ Weights } \\
\hline & 1 & 2 & 3 & 4 & 5 & 6 & 7 & 8 & & \\
\hline 1 & 3 & 5 & 6 & 8 & 7 & 6 & 3 & 8 & 46 & 0.0575 \\
\hline 2 & 3 & 5 & 6 & 8 & 8 & 6 & 3 & 8 & 47 & 0.05875 \\
\hline 3 & 15 & 5 & 7 & 3 & 12 & 2 & 4 & 2 & 50 & 0.0625 \\
\hline 4 & 13 & 12 & 7 & 5 & 2 & 2 & 11 & 4 & 56 & 0.0700 \\
\hline 5 & 13 & 12 & 7 & 6 & 13 & 2 & 2 & 2 & 57 & 0.07125 \\
\hline 6 & 2 & 12 & 4 & 5 & 5 & 11 & 10 & 10 & 59 & 0.07375 \\
\hline 7 & 15 & 12 & 10 & 11 & 13 & 11 & 11 & 11 & 94 & 0.1175 \\
\hline 8 & 7 & 7 & 9 & 10 & 12 & 11 & 11 & 8 & 75 & 0.09375 \\
\hline 9 & 7 & 7 & 10 & 10 & 8 & 10 & 11 & 8 & 71 & 0.08875 \\
\hline 10 & 5 & 5 & 6 & 5 & 2 & 10 & 9 & 5 & 47 & 0.05875 \\
\hline 11 & 7 & 7 & 5 & 9 & 10 & 8 & 7 & 5 & 58 & 0.0725 \\
\hline 12 & 3 & 4 & 7 & 7 & 2 & 6 & 7 & 7 & 43 & 0.05375 \\
\hline 13 & 3 & 2 & 6 & 6 & 2 & 6 & 6 & 10 & 41 & 0.05125 \\
\hline 14 & 2 & 2 & 5 & 2 & 2 & 6 & 2 & 6 & 27 & 0.03375 \\
\hline 15 & 2 & 3 & 5 & 5 & 2 & 3 & 3 & 6 & 29 & 0.03625 \\
\hline Total & 100 & 100 & 100 & 100 & 100 & 100 & 100 & 100 & 800 & 1.00 \\
\hline
\end{tabular}


Table 4. Ranking of Group 1 criteria

\begin{tabular}{|c|c|c|c|c|c|c|c|c|c|}
\hline \multirow{2}{*}{ Criterion } & \multicolumn{8}{|c|}{ Experts } & \multirow{2}{*}{$\begin{array}{c}\text { Sum } \\
\text { of } \\
\text { ranks }\end{array}$} \\
\hline & 1 & 2 & 3 & 4 & 5 & 6 & 7 & 8 & \\
\hline 1 & 1 & 1 & 1 & 1 & 1 & 1 & 1 & 1 & 8 \\
\hline 2 & 3 & 6 & 2 & 5 & 2 & 5 & 2 & 7 & 32 \\
\hline 3 & 4 & 5 & 7 & 2 & 3 & 6 & 7 & 6 & 40 \\
\hline 4 & 2 & 3 & 5 & 7 & 4 & 3 & 3 & 4 & 31 \\
\hline 5 & 5 & 4 & 6 & 6 & 7 & 7 & 6 & 5 & 46 \\
\hline 6 & 6 & 2 & 3 & 3 & 6 & 2 & 4 & 3 & 29 \\
\hline 7 & 7 & 7 & 4 & 4 & 5 & 4 & 5 & 2 & 38 \\
\hline
\end{tabular}

The concordance coefficient $W$ is calculated by the following formula (Kendal 1970):

$$
W=\frac{12 S}{r^{2} m\left(m^{2}-1\right)},
$$

where $r$ is the number of experts, $m$ is the number of the criteria evaluated.

The sum of squares $S$ is calculated according to the following scheme (Podvezko 2005, 2007):

1. Based on the data in Table $4, e_{i k}$ of expert estimates of each criterion's sum of ranks $e_{i}$ (Table 3 , last column) is calculated by the formula:

$$
e_{i}=\sum_{k=1}^{r} e_{i k}
$$

2. The mean value of ranks $\bar{e}$ is calculated by the formula:

$$
\bar{e}=\frac{\sum_{i=1}^{m} e_{i}}{m} .
$$

3. $S$, i. e. sum of squares of sum of ranks deviation $e_{i}$ from mean value $\bar{e}$ is calculated by the formula:

$$
S=\sum_{i=1}^{m}\left(e_{i}-\bar{e}\right)^{2} .
$$

In fact, the agreement level of expert estimates, which is determined not by the concordance coefficient $W$, but by $\chi^{2}$, the value associated with it, is calculated by the formula (Kendal 1970):

$$
\chi^{2}=W r(m-1)=\frac{12 S}{r m(m+1)} .
$$

It has been proved (Kendall, 1970) that if the value $\chi^{2}$ is larger than the critical value $\chi_{k r}^{2}$ taken from the table of $\chi^{2}$ distribution, with $v=m-1$ degrees of freedom and significance level $\alpha$ close to zero, then, a statistical hypothesis about the agreement of expert estimates is accepted.
The mean value of ranks $\bar{e}=224 / 7=32$ and concordance coefficient $\mathrm{W}=0.492$ were calculated based on the data presented in Table 5. The value of $\chi^{2}=23.625$ calculated by formula (18) exceeds the critical value $\chi_{k r}^{2}=12.592$, with the significance level $\alpha=0.05$ and $v=7-1=6$ degrees of freedom (Fisher, Yates 1963). This shows that expert estimates are in agreement and the criteria weights calculated based on expert judgements can be used in multicriteria evaluation.

The evaluation of Group 2 criteria by ranking is shown in Table 5.

Table 5. Ranking of Group 2 criteria

\begin{tabular}{cccccccccc}
\hline \multirow{2}{*}{ Criteria } & \multicolumn{8}{c}{ Experts } & Sum \\
\cline { 2 - 9 } & 1 & 2 & 3 & 4 & 5 & 6 & 7 & 8 & \\
\hline 1 & 10 & 9 & 10 & 6 & 8 & 11 & 11 & 4 & 69 \\
\hline 2 & 9 & 8 & 8 & 5 & 6 & 10 & 12 & 5 & 63 \\
\hline 3 & 2 & 10 & 6 & 14 & 3 & 15 & 10 & 14 & 74 \\
\hline 4 & 3 & 2 & 5 & 11 & 10 & 13 & 4 & 13 & 61 \\
\hline 5 & 4 & 3 & 7 & 9 & 2 & 14 & 14 & 15 & 68 \\
\hline 6 & 13 & 4 & 15 & 13 & 9 & 3 & 5 & 3 & 65 \\
\hline 7 & 1 & 1 & 1 & 1 & 1 & 1 & 1 & 1 & 8 \\
\hline 8 & 7 & 7 & 3 & 2 & 4 & 2 & 2 & 7 & 34 \\
\hline 9 & 6 & 6 & 2 & 3 & 7 & 4 & 3 & 6 & 37 \\
\hline 10 & 8 & 11 & 9 & 10 & 11 & 5 & 6 & 12 & 72 \\
\hline 11 & 5 & 5 & 13 & 4 & 5 & 6 & 7 & 11 & 56 \\
\hline 12 & 12 & 12 & 4 & 7 & 13 & 7 & 8 & 8 & 71 \\
\hline 13 & 11 & 15 & 11 & 8 & 12 & 8 & 9 & 2 & 76 \\
\hline 14 & 15 & 14 & 14 & 15 & 15 & 9 & 15 & 9 & 106 \\
\hline 15 & 14 & 13 & 12 & 12 & 14 & 12 & 13 & 10 & 100 \\
\hline
\end{tabular}

The mean value of ranks $\bar{e}=8298 / 15=553.2$ and concordance coefficient $W=0.463$ were calculated based on the data presented in Table 5. The value of $\chi^{2}=$ 51.56 calculated by formula (18) exceeds the critical value $\chi_{k r}^{2}=23.685$, with the significance level $\alpha=$ 0.05 and $v=15-1=14$ degrees of freedom (Fisher, Yates 1963). This shows that expert estimates are in agreement and the criteria weights calculated based on expert judgements can be used in multicriteria evaluation.

At the initial stage of evaluation it is convenient to determine the rank (position) of each object (enterprise) based on all the criteria used. The ranks of 24 enterprises calculated based on the criteria of Group 1 are given in Table 6.

The results of comparing 24 enterprises by four methods based on the criteria of Group 1 which were calculated by formulas (1)-(13) are given in Table 7. The method GV was not used because the values $r_{i j}$ of criteria from Table 2 were equal to zero. 
Table 6. Ranks of enterprises based on criteria of Group 1

\begin{tabular}{|c|c|c|c|c|c|c|c|c|c|c|c|c|c|c|c|c|c|c|c|c|c|c|c|c|}
\hline \multirow{2}{*}{ } & \multicolumn{24}{|c|}{ Enterprises } \\
\hline & 1 & 2 & 3 & 4 & 5 & 6 & 7 & 8 & 9 & 10 & 11 & 12 & 13 & 14 & 15 & 16 & 17 & 18 & 19 & 20 & 21 & 22 & 23 & 24 \\
\hline 1 & 10 & 22 & 7,5 & 4 & 2 & 24 & 13 & 11.5 & 23 & 17.5 & 16 & 14 & 7.5 & 4 & 4 & 20 & 9 & 1 & 11.5 & 21 & 19 & 15 & 17.5 & 6 \\
\hline 2 & 13.5 & 19 & 19 & 19 & 13.5 & 3.5 & 13.5 & 22.5 & 19 & 7.5 & 3.5 & 19 & 22.5 & 2 & 24 & 7.5 & 13.5 & 13.5 & 13.5 & 7.5 & 7.5 & 1 & 7.5 & 7.5 \\
\hline 3 & 7 & 4 & 6 & 17 & 17 & 17 & 5 & 24 & 14 & 8 & 9 & 20 & 23 & 3 & 1 & 22 & 21 & 11 & 17 & 13 & 12 & 2 & 10 & 17 \\
\hline 4 & 1 & 16 & 12.5 & 15 & 21 & 2 & 8 & 9.5 & 3 & 18 & 17 & 7 & 12.5 & 23 & 19 & 5 & 11 & 23 & 9.5 & 4 & 6 & 20 & 23 & 14 \\
\hline 5 & 8 & 1 & 16.5 & 16.5 & 16.5 & 16.5 & 16.5 & 16.5 & 16.5 & 3 & 5 & 16.5 & 16.5 & 6 & 7 & 16.5 & 16.5 & 16.5 & 16.5 & 16.5 & 16.5 & 4 & 2 & 16.5 \\
\hline 6 & 22.5 & 13.5 & 3.5 & 9 & 20 & 9 & 20 & 3.5 & 3.5 & 13.5 & 3.5 & 3.5 & 3.5 & 9 & 20 & 13.5 & 18 & 9 & 24 & 16.5 & 9 & 13.5 & 16.5 & 22.5 \\
\hline 7 & 13.5 & 21.5 & 11.5 & 6.5 & 13.5 & 21.5 & 10 & 6.5 & 11.5 & 21.5 & 3 & 3 & 3 & 1 & 16 & 6.5 & 21.5 & 16 & 21.5 & 9 & 18 & 21.5 & 6.5 & 16 \\
\hline 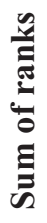 & 75.5 & 97 & 76.5 & 87 & 103.5 & 93.5 & 86 & 94 & 90.5 & 89 & 57 & 83 & 88.5 & 48 & 91 & 91 & 110.5 & 90 & 113.5 & 87.5 & 88 & 77 & 83 & 99.5 \\
\hline
\end{tabular}

Table 7. General estimates of aid criteria obtained by multicriteria methods

\begin{tabular}{|c|c|c|c|c|c|c|c|c|c|c|c|c|c|c|}
\hline \multirow{3}{*}{ 总 } & \multicolumn{14}{|c|}{ Multicriteria evaluation methods } \\
\hline & \multicolumn{2}{|c|}{ SAW } & \multicolumn{2}{|c|}{ VS } & \multicolumn{2}{|c|}{ TOPSIS } & \multicolumn{8}{|c|}{ VIKOR } \\
\hline & $S_{j}$ & Rank & $V_{j}$ & Rank & $C_{j}^{*}$ & Rank & $S_{j}$ & Rank & $R_{j}$ & Rank & $Q_{j}$ & Rank & $\begin{array}{c}\text { Sum of } \\
\text { ranks }\end{array}$ & $\begin{array}{c}\text { Ultimate } \\
\text { rank }\end{array}$ \\
\hline 1 & 0.0404 & 8 & 75.5 & 3 & 0.320 & 6 & 0.636 & 13 & 0.134 & $2-3$ & 0.304 & 7 & 39.5 & 2 \\
\hline 2 & 0.0447 & 5 & 97 & 20 & 0.261 & $17-19$ & 0.722 & 22 & 0.203 & 22 & 0.720 & 23 & 110 & 23 \\
\hline 3 & 0.0355 & $14-15$ & 76.5 & 4 & 0.261 & $17-19$ & 0.573 & 7 & 0.140 & $5-6$ & 0.242 & 6 & 55 & 9 \\
\hline 4 & 0.0348 & 18 & 87 & 9 & 0.274 & 13 & 0.555 & 4 & 0.140 & $5-6$ & 0.216 & 3 & 52.5 & 8 \\
\hline 5 & 0.0280 & 22 & 103.5 & 22 & 0.270 & $15-16$ & 0.664 & 17 & 0.152 & 12 & 0.419 & 15 & $103 . .5$ & 20 \\
\hline 6 & 0.0417 & 7 & 93.5 & 18 & 0.337 & 4 & 0.663 & 16 & 0.245 & 24 & 0.821 & 24 & 93 & 17 \\
\hline 7 & 0.0346 & 19 & 86 & 8 & 0.243 & $20-21$ & 0.682 & 19 & 0.135 & 4 & 0.368 & 10 & 80.5 & 13 \\
\hline 8 & 0.0355 & $14-15$ & 94 & 19 & 0.270 & $15-16$ & 0.562 & 6 & 0.143 & $7-8$ & 0.238 & 4 & 66.5 & 10 \\
\hline 9 & 0.0349 & 17 & 90.5 & 15 & 0.289 & $8-9$ & 0.633 & 12 & 0.229 & 23 & 0.710 & 22 & 97.5 & 19 \\
\hline 10 & 0.0376 & 11 & 89 & 13 & 0.222 & 22 & 0.732 & 23 & 0.183 & $17-18$ & 0.647 & 21 & 107.5 & 22 \\
\hline 11 & 0.0525 & 4 & 57 & 2 & 0.321 & 5 & 0.556 & 5 & 0.181 & 16 & 0.399 & 13 & 45 & 4 \\
\hline 12 & 0.0375 & 12 & 83 & $6-7$ & 0.282 & 11 & 0.551 & 3 & 0.147 & 10 & 0.240 & 5 & 47.5 & $5-6$ \\
\hline 13 & 0.0359 & 13 & 88.5 & 12 & 0.280 & 12 & 0.530 & 2 & 0.143 & $7-8$ & 0.195 & 2 & 48.5 & 7 \\
\hline 14 & 0.0703 & 3 & 48 & 1 & 0.458 & 3 & 0.429 & 1 & 0.155 & $13-14$ & 0.111 & 1 & 22.5 & 1 \\
\hline 15 & 0.0852 & 1 & 91 & $16-17$ & 0.471 & 2 & 0.615 & 11 & 0.144 & 9 & 0.317 & 8 & 47.5 & $5-6$ \\
\hline 16 & 0.0401 & 9 & 91 & $16-17$ & 0.295 & 7 & 0.604 & 10 & 0.191 & 20 & 0.506 & 16 & 78.5 & 12 \\
\hline 17 & 0.0269 & 23 & 110.5 & 23 & 0.219 & 23 & 0.718 & 21 & 0.134 & $2-3$ & 0.417 & 14 & 106.5 & 21 \\
\hline 18 & 0.0305 & $20-21$ & 90 & 14 & 0.284 & 10 & 0.588 & 9 & 0.155 & $13-14$ & 0.328 & 9 & 76 & 11 \\
\hline 19 & 0.0251 & 24 & 113.5 & 24 & 0.212 & 24 & 0.794 & 24 & 0.151 & 11 & 0.593 & 19 & 126 & 24 \\
\hline 20 & 0.0387 & 10 & 87.5 & 10 & 0.289 & $8-9$ & 0.641 & 14 & 0.200 & 21 & 0.596 & 20 & 83.5 & 14 \\
\hline 21 & 0.0353 & 16 & 88 & 11 & 0.271 & 14 & 0.657 & 15 & 0.186 & 19 & 0.557 & 17 & 92 & 16 \\
\hline 22 & 0.0801 & 2 & 77 & 5 & 0.504 & 1 & 0.578 & 8 & 0.169 & 15 & 0.373 & 11 & 42 & 3 \\
\hline 23 & 0.0428 & 6 & 83 & $6-7$ & 0.261 & $17-19$ & 0.673 & 18 & 0.183 & $17-18$ & 0.566 & 18 & 84 & 15 \\
\hline 24 & 0.0305 & $20-21$ & 99.5 & 21 & 0.243 & $20-21$ & 0.709 & 20 & 0.129 & 1 & 0.384 & 12 & 95 & 18 \\
\hline
\end{tabular}


The results of the same analysis based on the criteria of Group 2 are provided in Table 8.

As shown in Tables 7, 8, the estimates obtained by a compromise classification methods VIKOR differ from the results yielded by other methods. The above approach yields indeterminate values for enterprises having at least one criterion estimated to be equal to zero. It follows that the method VIKOR should be cautiously used in the analysis.

Table 8. General estimates of criteria describing aid effect obtained by multicriteria methods

\begin{tabular}{|c|c|c|c|c|c|c|c|c|c|c|c|c|c|c|}
\hline \multirow{3}{*}{ 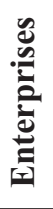 } & \multicolumn{14}{|c|}{ Estimates obtained by multicriteria methods } \\
\hline & \multicolumn{2}{|c|}{ SAW } & \multicolumn{2}{|c|}{ VS } & \multicolumn{2}{|c|}{ TOPSIS } & \multicolumn{8}{|c|}{ VIKOR } \\
\hline & $S_{j}$ & Rank & $V_{j}$ & Rank & $C_{j}^{*}$ & Rank & $S_{j}$ & Rank & $R_{j}$ & Rank & $Q_{j}$ & Rank & $\begin{array}{c}\text { Sum of } \\
\text { ranks }\end{array}$ & $\begin{array}{c}\text { Ultimate } \\
\text { rank }\end{array}$ \\
\hline 1 & 0.0349 & 17 & 217.5 & 17 & 0.309 & 17 & 0.624 & 17 & 0.064 & 11 & 0.335 & 13 & 92 & 16 \\
\hline 2 & 0.0462 & 10 & 158.5 & 8 & 0.375 & 12 & 0.442 & 9 & 0.059 & $1-9$ & 0.159 & 8 & 52 & 8 \\
\hline 3 & 0.0446 & 11 & 191 & 14 & 0.379 & 11 & 0.535 & 13 & 0.073 & $13-17$ & 0.341 & 14 & 78 & 13 \\
\hline 4 & 0.0379 & 16 & 190.5 & 13 & 0.343 & 15 & 0.540 & 14 & 0.073 & $13-17$ & 0.345 & 15 & 88 & 15 \\
\hline 5 & 0.0247 & 19 & 251 & 20 & 0.204 & 21 & 0.806 & 21 & 0.118 & $21-24$ & 0.915 & 22 & 125.5 & 21 \\
\hline 6 & 0.0410 & 13 & 166.5 & 9 & 0.357 & 14 & 0.460 & 11 & 0.073 & $13-17$ & 0.288 & 11 & 73 & 10 \\
\hline 7 & 0.0503 & $7-8$ & 145 & 6 & 0.425 & 7 & 0.368 & 7 & 0.059 & $1-9$ & 0.107 & 6 & 38.5 & $5-6$ \\
\hline 8 & 0.0891 & 1 & 135.5 & 5 & 0.567 & 1 & 0.332 & 5 & 0.073 & $13-17$ & 0.198 & 9 & 43 & 7 \\
\hline 9 & 0.0406 & 14 & 170 & 10 & 0.387 & 10 & 0.498 & 12 & 0.074 & $18-19$ & 0.326 & 12 & 76.5 & 12 \\
\hline 10 & 0.0330 & 15 & 212.5 & 16 & 0.315 & 16 & 0.591 & 16 & 0.073 & $13-17$ & 0.380 & 16 & 94 & $17-18$ \\
\hline 11 & 0.0598 & $3-5$ & 88 & $1-3$ & 0.458 & $3-5$ & 0.217 & $1-3$ & 0.059 & $1-9$ & 0 & $1-3$ & 19 & $1-3$ \\
\hline 12 & 0.0598 & $3-5$ & 88 & $1-3$ & 0.458 & $3-5$ & 0.217 & $1-3$ & 0.059 & $1-9$ & 0 & $1-3$ & 19 & $1-3$ \\
\hline 13 & 0.0598 & $3-5$ & 88 & $1-3$ & 0.458 & $3-5$ & 0.217 & $1-3$ & 0.059 & $1-9$ & 0 & $1-3$ & 19 & $1-3$ \\
\hline 14 & 0.0162 & 23 & 272 & 21 & 0.138 & 23 & 0.875 & 23 & 0.118 & $21-24$ & 0.963 & 23 & 135.5 & 24 \\
\hline 15 & 0.0185 & 22 & 275 & 23 & 0.148 & 22 & 0.837 & 22 & 0.078 & 20 & 0.603 & 19 & 128 & 23 \\
\hline 16 & 0.0540 & 6 & 199 & 15 & 0.443 & 6 & 0.541 & 15 & 0.118 & $21-24$ & 0.728 & 20 & 84,5 & 14 \\
\hline 17 & 0.0128 & 24 & 297 & 24 & 0.091 & 24 & 0.927 & 24 & 0.059 & $1-9$ & 1 & 24 & 125 & 22 \\
\hline 18 & 0.0445 & 12 & 173.5 & 11 & 0.371 & 13 & 0.439 & 8 & 0.118 & $21-24$ & 0.157 & 7 & 73,5 & 11 \\
\hline 19 & 0.0241 & 20 & 242 & 19 & 0.232 & 19 & 0.738 & 19 & 0.065 & 12 & 0.867 & 21 & 110 & 19 \\
\hline 20 & 0.0276 & 18 & 241.5 & 18 & 0.247 & 18 & 0.693 & 18 & 0.059 & $1-9$ & 0.391 & 17 & 94 & $17-18$ \\
\hline 21 & 0.0503 & $7-8$ & 148 & 7 & 0.412 & 8 & 0.346 & 6 & 0.059 & $1-9$ & 0.091 & 5 & 38,5 & $5-6$ \\
\hline 22 & 0.0604 & 2 & 96 & 4 & 0.473 & 2 & 0.268 & 4 & 0.059 & $1-9$ & 0.036 & 4 & 21 & 4 \\
\hline 23 & 0.0469 & 9 & 180 & 12 & 0.401 & 9 & 0.458 & 10 & 0.063 & 10 & 0.202 & 10 & 60 & 9 \\
\hline 24 & 0.0229 & 21 & 274 & 22 & 0.224 & 20 & 0.748 & 20 & 0.074 & $18-19$ & 0.502 & 18 & 119.5 & 20 \\
\hline
\end{tabular}

\subsection{The results of business aid analysis}

The values relating to aid and its effect, calculated by various multicriteria methods, were grouped and presented as a graph (Figs. 1, 2, 3).

The results presented allow us to state that aid effect on the development of projects for providing services differs from that observed in other areas. The influence of the types of subsidies to these projects on the effect of aid is null. The effect itself is also the smallest compared to that produced in other areas. For these purposes, seeking to determine the relation between the nature of the aid and the effect produced by it, the data on the projects of supporting the development of services were not considered in further analysis. In calculating the correlation coefficients, the values greatly deviating from others were not used either.

The strength of correlation characterizes the relationship between aid and its effect. The estimates obtained by using different methods as well as the calculated correlation coefficients allow us to state that the size and nature of subsidies directly affect the results of assistance. It has been found that aid intensity (aid share of project value), rather than absolute aid value, has a greater impact: the higher the intensity, the greater the effect. 


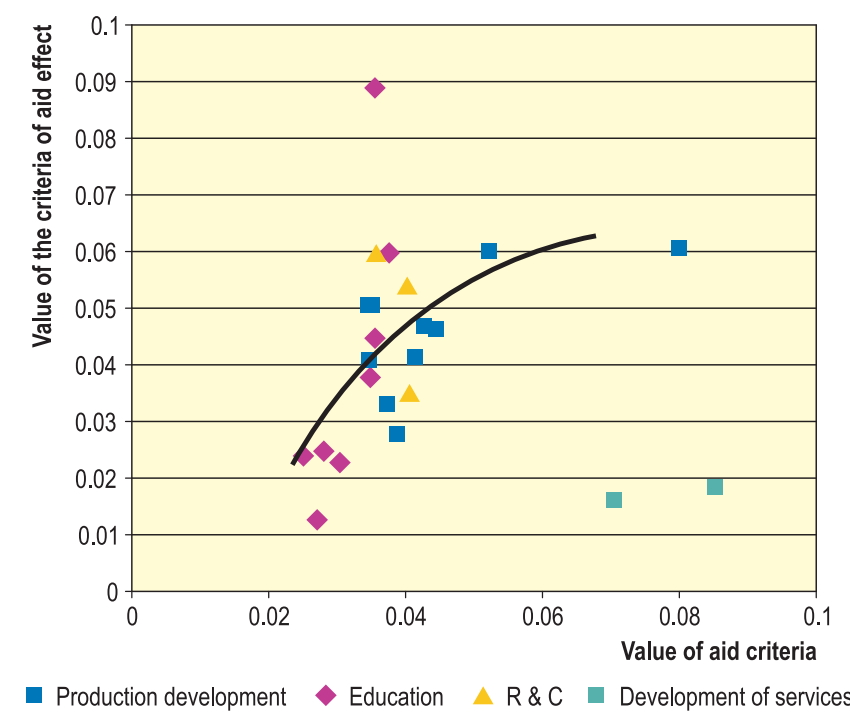

Fig. 1. The effect of aid to enterprises according to the areas of their activities calculated by SAW

(correlation coefficient -0.62 )

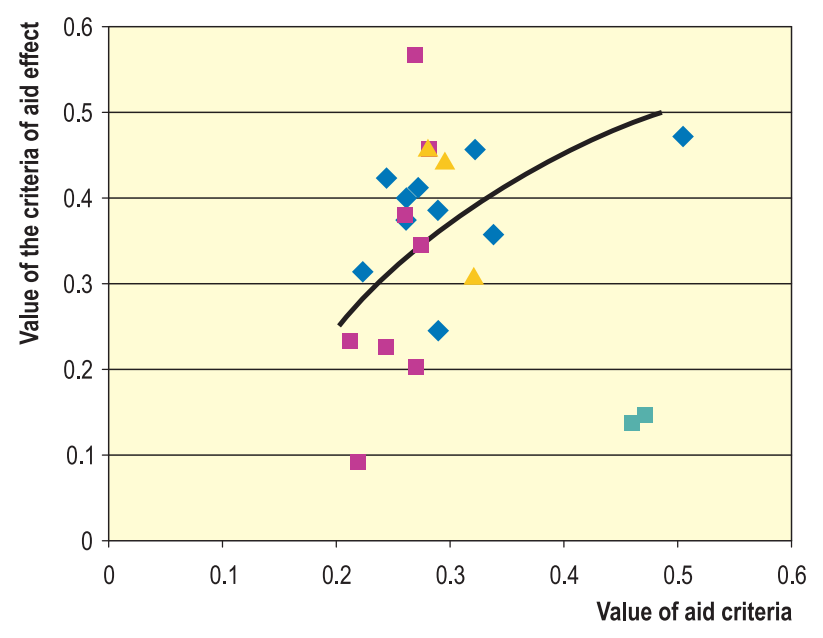

Production development $\triangleleft$ Education $\triangle R \& D \square$ Development of services

Fig. 2. The effect of aid to enterprises according to the areas of their activities calculated by TOPSIS

(correlation coefficient -0.48 )

Assessing project financing by the borrowed or own capital, experts believe that the latter is more important. Since higher aid intensity directly affects, i.e. reduces the share of own enterprise capital used for financing, it can be stated that, seeking better results, the priority should be given to the increase of project financing through the EU funds rather than to the increase of enterprise share of financing. The calculated correlation coefficients allow us to conclude that criteria used in the study to describe state subsidies are not the only factors determining the effect of the EU aid to businesses. It can be stated that such factors as the particular market environment in which an enterprise is operating, qualification of project contractors,

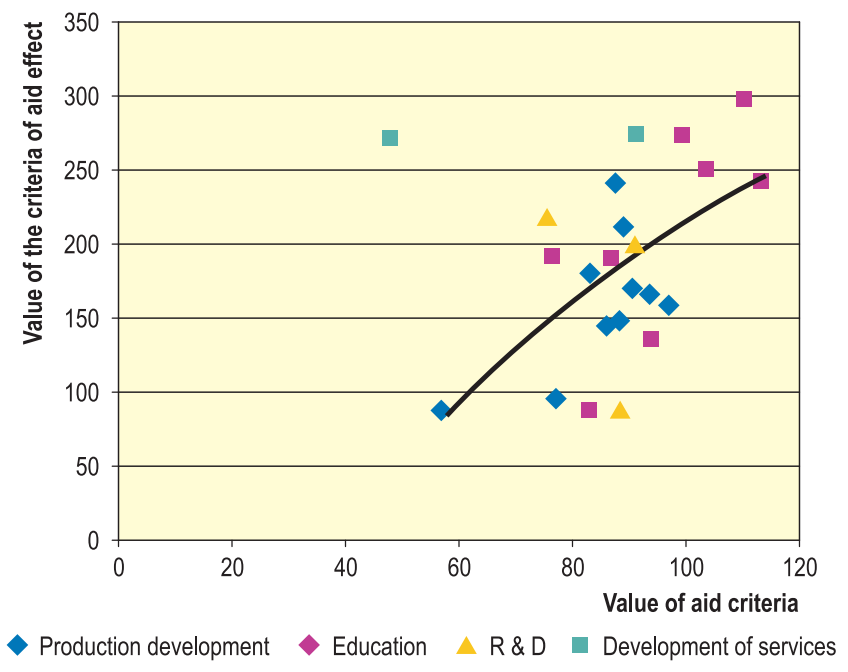

Fig. 3. The effect of aid to enterprises according to the areas of their activities calculated by VS

(correlation coefficient -0.62 )

flexibility of administration staff of an institution, the interest of enterprise staff in project implementation, etc. also have a certain impact on project execution and the results obtained.

Assessing aid effect, taking into account various types of businesses which are granted the EU aid, it can be stated that the best results are obtained when aid is granted to development of production, research \& development and education. It should be noted that the aid to the increase of production and research \& development is associated with infrastructure's development projects, to which large financial resources are allocated in terms of absolute value. Though the effect of aid projects in the area of education is lower, the difference from much more expensive projects aimed at infrastructure's development is slight because educational projects requisre considerably smaller amounts of financial resources. Therefore, it can be stated that their effectiveness is much higher.

The results obtained show that, using multicriteria evaluation methods, it is possible to assess the effect of state aid to business from various perspectives, determining, first, the most influencing aid criteria and, second, identifying the areas of activities to which state aid should be granted.

\section{Conclusions}

1. Many researchers from the EU member-states and other countries of the world are considering the problem of state aid to business. The aid and its effects are described by sets of criteria. Therefore, there is hardly a single criterion which could ad- 
equately describe effect of state-granted subsidies, allowing us to compare the results of subsidizing various areas of activities by the state. The objective evaluation of state aid and its effects may be made by applying multicriteria evaluation methods.

2. Multicriteria evaluation methods differ in their complexity. The most widely known and used method is SAW. The simplest approach is VS. The calculations show that its use is justified at the initial stage of evaluation, though the results obtained by using this method, i.e. the ranking of the considered objects, do not differ much from those yielded by more sophisticated mathematical approaches. In the present work, complex evaluation of the effects produced by state aid (subsidies) to enterprises is based both on the use of the simplest and more sophisticated methods, such as TOPSIS and VIKOR. VIKOR yielded indeterminate results for enterprises having at least one criterion estimate equal to zero. Therefore, it was considered unsuitable for further analysis and not used any longer.

3. The analysis of state aid by the methods SAW, VS and TOPSIS allowed us to calculate two criteria for the enterprises considered. One of these criteria described the type of aid (subsidies), while the second demonstrated its effects. By grouping the criteria describing the phenomenon considered, it can be stated that the type of aid influences the development of production, research \& development and educational projects. The data obtained in analysing the effect of aid on the development of enterprises providing services differ considerably from the results obtained in other areas of investigation. Even when the values of criteria describing subsidies in the projects of this area were large, the effects produced were considerably lower.

4. The analysis has shown that the key factor, determining the EU and state aid effect on developing production, research \& development and educational projects is aid intensity (the higher the intensity, the greater the effect). The best ratio of investments to the results achieved is in the area of educational projects. It is followed by research \& development and industrial projects. The lowest effectiveness of aid was observed at enterprises providing services.

5. The results obtained in analysing the effect of state aid to business by multicriteria evaluation methods have shown the effectiveness of their application to the investigation of this process. They provide an objective view of the situation.

\section{References}

Bachtler, J.; Michie, R. 1995. A new era in EU regional policy evaluation? The appraisal of the structural funds, Regional Studies 8(29): 745-751.

Bardauskiene, D. 2007. The expert's estimates application in the preparation of city general plan, Technological and Economic Development of Economy 13(3): 223- 236.

Besley, T.; Seabright, P. 1998. The effects and policy implications of state aids to industry: An economic analysis, Economic Policy 14(28): 13-53.

Black, D.; Hoyt, W. 1989. Bidding for firms, American Economic Review 5(79): 1249-1256.

Bond, E.; Samuelson, L. 1986. Tax holidays as signals, American Economic Review 4(76): 820-826.

Chen, H. 1990. Theory-driven Evaluations. London: Sage Publications. $330 \mathrm{p}$.

Doyle, C.; van Wijnbergen, S. 1984. Taxation of foreign multinationals: A Sequential bargaining approach to tax holidays, CEPR Discussion Papers 25: 15-17.

Figueira, J.; Greco, S.; Ehrgott, M. 2005. Multiple Criteria Decision Analysis: State of the Art Survey. Boston: Kluwer Academic Publishers. 107 p.

Fisher, R. A.; Yates, F. 1963. Statistical Tables for Biological, Agricultural and Medical Research, $6^{\text {th }}$ ed. London: Oliver and Boyd. $156 \mathrm{p}$.

Ginevičius, R. 2008. Normalization of quantities of various dimensions, Journal of Business, Economics and Management 9(1): 79-86.

Ginevičius, R.; Butkevičius, A.; Podvezko, V. 2005. Multicriteria evaluation of economic development of new memberstates of the European Union, Business: Theory and Practice 6(2): 85-93.

Ginevičius, R.; Butkevičius, A.; Podvezko, V. 2006. Complex evaluation of economic development of the Baltic states and Poland, Ekonomický Časopis [Journal of Economics] 9(54): 918-930.

Ginevičius, R.; Podvezko, V. 2001. Complex evaluation of economic-social development of Lithuanian regions, Civil Engineering 7(4): 304-309.

Ginevičius, R.; Podvezko, V. 2004a. Complex evaluation of the use of information technologies in the countries of Eastern and Central Europe, Journal of Business Economics and Management 5(4): 183-191.

Ginevičius, R.; Podvezko, V. 2004b. Quantitative evaluation of strategic potential of enterprises, Business: Theory and Practice 5(1): 3-9.

Ginevičius, R.; Podvezko, V. 2004c. Assessing the accuracy of expert methods, Engineering Economics 5(40): 7-12.

Ginevičius, R.; Podvezko, V. 2005. Developing a set of evaluation criteria, Business: Theory and Practice 6(4): 199-207. 
Ginevičius, R.; Podvezko, V. 2006. Assessing the financial state of construction enterprises, Technological and Economic Development of Economy 12(3): 188-194.

Ginevičius, R.; Podvezko, V. 2007a. Some problems of evaluating multicriteria decision methods, International Journal of Management and Decision Making 8(5/6): 527-539.

Ginevičius, R.; Podvezko, V. 2007b. Complex assessment of sustainable development of state regions with emphasis on ecological and dwelling conditions, Ecology 53 (Supplement): 41-48.

Ginevičius, R.; Podvezko, V.; Andruškevičius, A. 2004. Determining the effectiveness of building systems by AHP technique, Technological and Economic Development of Economy 10(4): 135-141.

Ginevičius, R.; Podvezko, V.; Mikelis, D. 2004. Quantitative evaluation of economic and social development of Lithuanian Regions, Economics: proceedings 65: 67-81.

Guba, E.; Lincoln, Y. 1981. Effective evaluation: improving the usefulness of evaluation results through responsive and naturalistic approaches. San Francisco: Jossey-Bass. $423 \mathrm{p}$.

Guba, E.; Lincoln, Y. 1989. Fourth Generation Evaluation. London: Sage Publications. 295 p.

Hagens, J. S.; Bekker, M. H.; Gaaff, A. 1994. Framework for the evaluation of regional policy, in $34^{\text {th }}$ European Congress of the Regional Science Association. Groningen: TERP Advies, PIETER VAN RUN Consultancy Bureau of European Affairs (CBEA), 23-26.

Hwang, C.L.; Yoon, K. 1981. Multiple attribute decision making-methods and applications. A state of the art survey. Berlin, Heidelberg, New York.

Kalibatas, D.; Turskis, Z. 2008. Multicriteria evaluation of inner climate by using MOORA method, Information Technology and Control 37(1): 79-83.

Keen, M. \& Marchand, M. 1997. Fiscal competition and the pattern of public spending, Journal of Public Economics 1(66): 33-53.

Kendall, M. 1970. Rank Correlation Methods. $4^{\text {th }}$ ed. London: Griffin,

Lithuanian General Programming Document for the years 2004-2006, 2004. Vilnius, Elfrata.

Nicolaides, P.; Kekelekis, M; Buyskes, P. 2005. State Aid Policy in the European Community. The Hague: Kluwer Law International. $137 \mathrm{p}$.

Opricovic, S.; Tzeng, G.-H. 2004. Compromise solution by MCDM methods: A comparative analysis of VIKOR and TOPSIS, European Journal of Operational Research 156: 445-455.

Patton, M. Q. 1986. Utilization-Focused Evaluation. Beverly Hills: Sage Publications.

Patton, M. Q. 1996. A world larger than formative and summative, Evaluation Practice 2(17): 131-144.
Podvezko, V. 2005. The agreement of expert estimates, Technological and Economic Development of Economy 11(2): 101-107.

Podvezko, V. 2007. Determining the level of agreement of expert estimates, International Journal of Management and Decision Making 8(5/6): 586-600.

Rossi, P. H.; Freeman, H. E. 1989. Evaluation. A Systematic Approach. CA Beverly Hills: Sage Publications.

Saaty, T. L. 1980. The Analytic Hierarchy Process. New York: M. Graw-Hill.

Scriven, M. 1967. The Methodology of Evaluation. Chicago: Rand McNally.

Scriven, M. 1991. Beyond Formative and Summative Evaluation. Chicago: University of Chicago Press.

Shadish W.; Cook, T.; Leviton, L. 1991. Foundations of Program Evaluation. CA New Park: Sage Publications.

Tamošiūnienė, R.; Šidlauskas, S.; Trumpaitè, I. 2006. Evaluating the investment projects by multicriteria methods, Business: Theory and Practice 7(4) 203-208.

Turskis, Z.; Zavadskas, E. K.; Zagorskas, J. 2006. Sustainable city compactness evaluation on the basis of GIS and Bayes rule, International Journal of Strategic Property Management 10(3): 185-207.

Ustinovichius, L.; Zavadskas, E. K.; Podvezko, V. 2007. Application of a quantitative multiple criteria decision making (MCDM-1) approach to the analysis of investments in construction, Control and Cybernetics 35(2): 251-268.

Venetoklis, T. 1998. Evaluation and monitoring of business aid in Finland. Applicant enterprises projects and distributors of aid in industrially declining regions. A Quantitative Approach, VATT Discussion Papers 169: 1.

Viteikienè, M.; Zavadskas, E. K. 2007. Evaluating the sustainability of Vilnius city residential areas, Journal of Civil Engineering and Management 13(2): 149-155.

Zavadskas, E. K.; Kaklauskas, A. 2007. Mehrzielselektion für Entscheidungen im Bauwessen [Multi-attribute decisions in construction]. Fraunhofer IRB Verlag.

Zavadskas, E. K.; Turskis, Z. 2008. A new logarithmic normalization method in games theory, Informatica 19(2): 303-314.

Zavadskas, E. K.; Vilutiené, T. 2006. A multiple criteria evaluation of multi-family apartment block's maintenance contractors: I-Model for maintenance contractor evaluation and the determination of its selection criteria, Building and Environment 41(5): 621-632.

Zavadskas, E. K.; Zakarevičius, A.; Antuchevičienè, J. 2006. Evaluation of ranking accuracy in multi-criteria decisions, Informatica 17(4): 601-618.

State Aid Control. 2007 [accessed on December 17, 2008]. Available from Internet: $<$ http://ec.europa.eu/comm/competition/state_aid/studies_reports/stat_tables.html $>$.

State Aid Control. 2007 [accessed on December 15, 2007]. Available from Internet:_<http://www.konkuren.lt/vp/index. php?show=leidiniai $>$. 